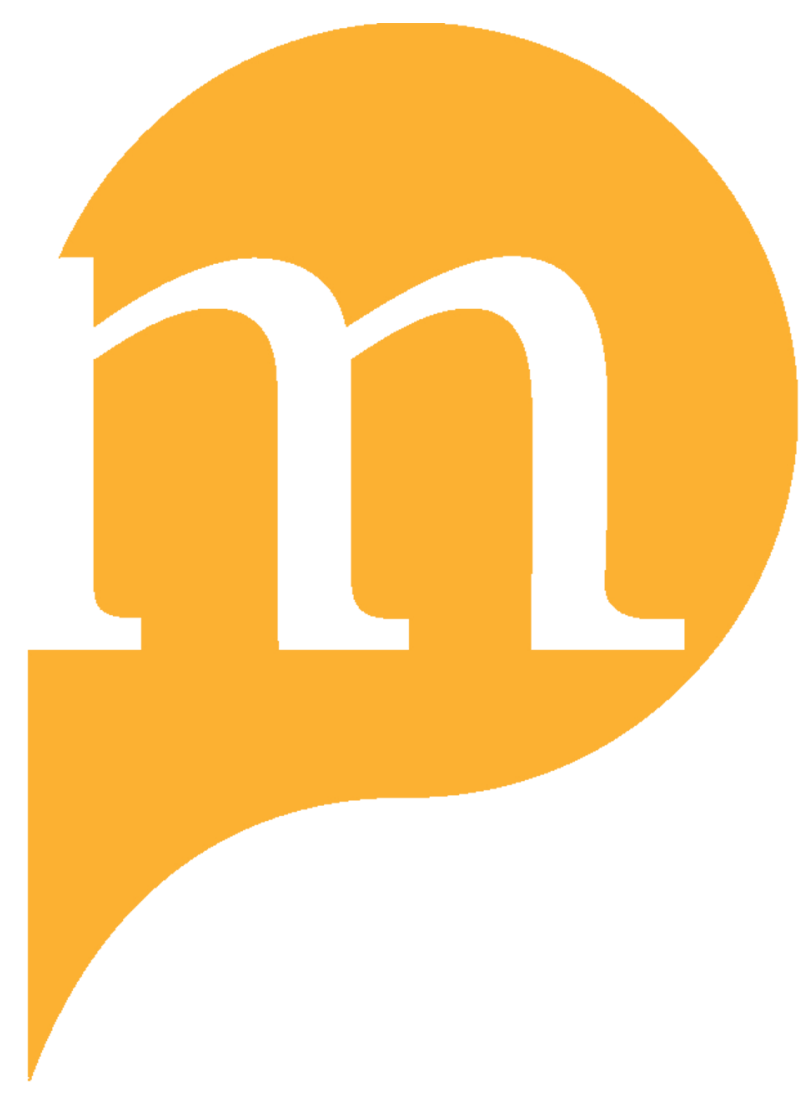

PROJECT MUSE 


\title{
Gasoline Station Morphology on Virginia's Eastern Shore
}

\author{
BRADLEY D. MACPHERSON \\ Salisbury University
}

MARK DE SOCIO

Salisbury University

\begin{abstract}
Gasoline stations are a ubiquitous component of the modern built environment. Gasoline stations are largely included within people's daily spatial routines given the nature of modern transportation, particularly in mobile societies like the United States, and represent a material infrastructure that underlies and facilitates daily economic activities. As such, gasoline stations are generally relegated to the background of contemporary cultural landscapes because the action of obtaining gasoline for one's vehicle has become such a routine and mundane activity that it is hardly given any forethought. Yet, the changing form and function of gasoline stations (hence the term "morphology") along with changing technologies in transportation and transportation infrastructure has rendered many gasoline stations obsolete. Utilizing nearest neighbor analysis, this paper identifies and documents changing spatial patterns and functions of gasoline station locations throughout Virginia's Eastern Shore by decade and documents changing cultural and economic uses of recycled gasoline stations.
\end{abstract}

Las estaciones de gasolina son un componente ubicuo del medio ambiente moderno construido. Las estaciones de gasolina están en gran parte incluidas en las rutinas diarias espaciales de las personas, dada la naturaleza de los medios de transporte modernos, sobre todo en las sociedades móviles, como los Estados Unidos, y representan una infraestructura material que sirve de base y facilita las actividades económicas diarias. Por lo tanto, las estaciones de gasolina están generalmente relegadas a un segundo plano en los paisajes culturales contemporáneos porque la acción de obtener gasolina para nuestros vehículos se ha convertido en una actividad rutinaria y mundana que casi nunca se toma en consideración. Sin embargo, el cambio de forma y función de las estaciones de gasolina (de ahí el término "morfología") junto con los cambios tecnológicos en el transporte y la infraestructura de transporte han hecho obsoletas muchas estaciones de gasolina. Utilizando análisis de cercanía de vecindario, este trabajo identifica y documenta el cambio de patrones espaciales y funciones de la ubicación de las estaciones de gasolina en toda la costa este de Virginia, por décadas, y documenta los cambios de usos culturales y económicos de las estaciones recicladas de gasolina.

KEY WORDS: Retail location, gasoline stations, vernacular landscapes, Virginia, Virginia Eastern Shore

PALABRAS CLAVE: localización de venta al detal, estaciones de gasolina, paisajes vernaculares, Virginia, costa este de Virginia 


\section{INTRODUCTION}

Located on the southern end of the nearly 6,000 square mile $\left(15,540 \mathrm{~km}^{2}\right)$ Delmarva Peninsula, the Eastern Shore of Virginia is geographically isolated from the remainder of the state (Figure 1). Comprised of two counties, Accomack to the north and Northampton to the south, the Eastern Shore is physically separated from the Virginia mainland by the Chesapeake Bay, which is less than 14 miles (22 $\mathrm{km})$ at its narrowest point between Northampton County to the east and Mathews County to the west, and more than 30 miles $(48 \mathrm{~km})$ at its widest between Accomack County to the east and Northumberland County to the west. Consequently, spatial interaction between Virginia's Eastern Shore and the Virginia mainland was mostly limited to water traffic until the Chesapeake Bay Bridge-Tunnel, spanning 17.6 miles $(28.3 \mathrm{~km})$ across the mouth of the bay and linking the City of Norfolk with the southern tip of the Delmarva Peninsula, opened in 1964. Before then, ferries shuttled passengers and vehicles between Norfolk and the town of Cape Charles, located at the southwestern end of Delmarva. In 1884, a rail line was completed that ran from Philadelphia, PA, to Cape Charles. Barges and ferries linked the railroad at Cape Charles with the rail yards in Norfolk. Despite the railroad and completion of the bridge-tunnel eighty years later, spatial interaction between Virginia's Eastern Shore and the Virginia mainland remains relatively cumbersome and limited. Consequently, much of the Virginia Eastern Shore has changed very little over the decades. It is largely rural and its limited number of towns primarily face the Chesapeake Bay.
Geographical isolation of Virginia's Eastern Shore has not left it entirely unchanged, however. Wider economic forces like the decline in commercial fishing and the consolidation of rural family farmsteads into larger corporate farms have created what is arguably a 'derelict' rural landscape (Jakle and Wilson 1992). Over the decades, population stagnation and loss has left a rural landscape dotted with farmhouses left abandoned and deteriorating in isolation. Signs of economic decline amid abandoned and deteriorating buildings-all relics of a bygone era-are likewise prevalent in most of the towns along Virginia's Eastern Shore. One particular type of structure that significantly adds to the appearance of a derelict rural landscape is the prevalence of a large number of abandoned and recycled gasoline stations that are located throughout the length of Virginia's Eastern Shore ${ }^{1}$ (Figures 2 and 3). The sheer number of abandoned and recycled gasoline stations suggests changing patterns in gasoline station locations through time. It also portends a unique and changing role of the gasoline station in rural and 'roadside' American life given the various styles of architecture found among them. Indeed, some styles appear to predate others, and location sites and styles of architecture appear to be similar among gasoline stations that appear to be of similar age. The objective of this paper, then, is to identify and explore changing spatial patterns and functions of gasoline station locations on Virginia's Eastern Shore.

The paper draws primarily on two separate bodies of literature. Utilizing the authoritative works of geographer John Jakle (Jakle 1978; Jakle and Wilson 1992; Jakle and Sculle 1994), the paper explores gas- 


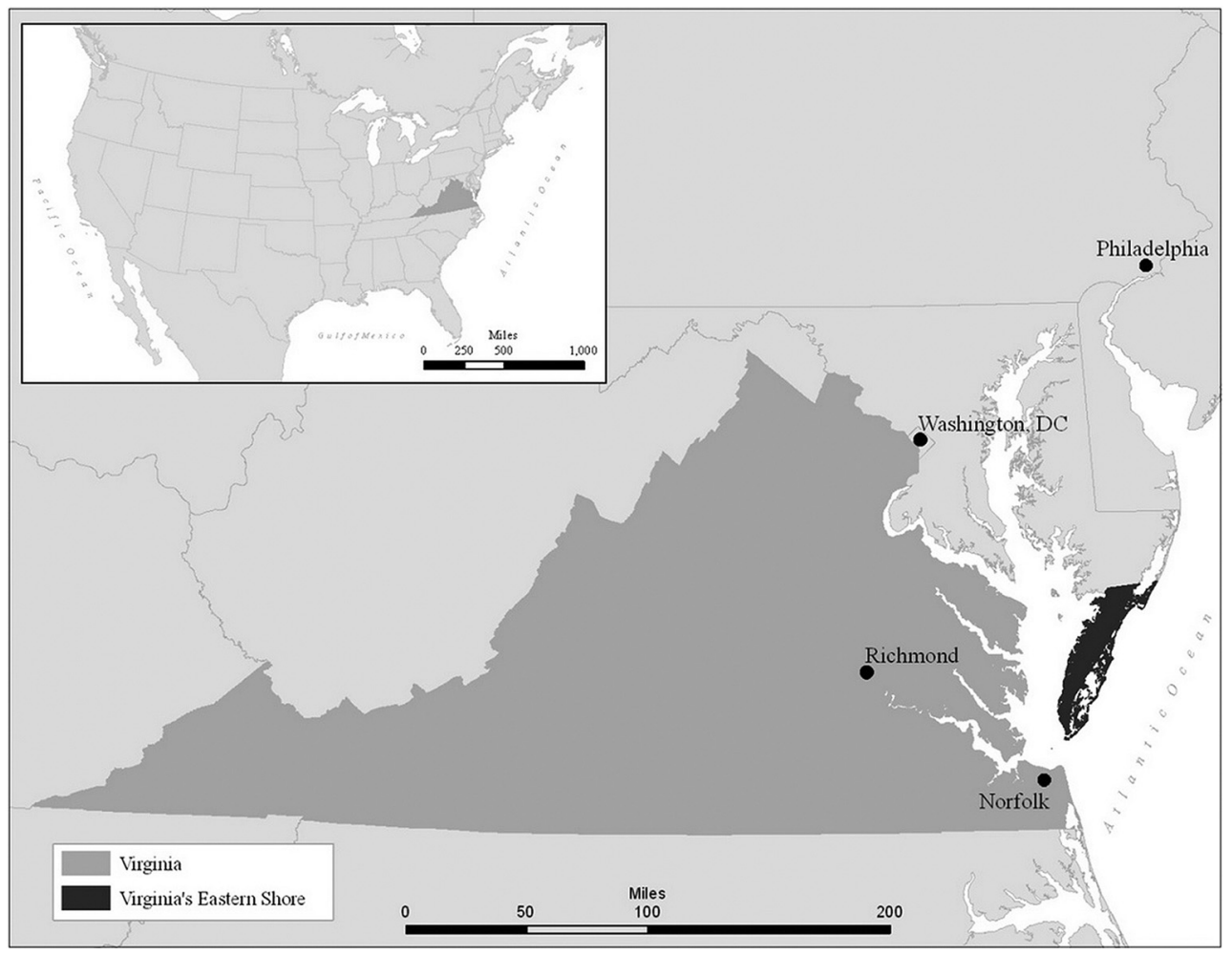

Figure 1. Study area: Virginia's Eastern Shore relative to Virginia and the Middle Atlantic region of the United States.

oline stations as part of a cultural vernacular roadside landscape that was at one time uniquely American. Here, various gasoline station architectures and their economic and cultural functions are explored. Second, literature regarding classical retail location modeling is explored with the aim of situating patterns of gasoline station locations within a logic of capitalist competition and change. Data and methodology (namely, nearest neighbor analyses for gasoline station locations by decade built) are then presented followed by results and concluding remarks.
THE GASOLINE STATION IN

\section{AMERICAN CULTURE}

The gasoline service station as 'place' is a uniquely identifiable architectural structure that serves an important and particular function in the modern built environment, both urban and rural-that of fueling, at the retail level, the automobiles that are so central to the daily functioning of the modern global economy. Gasoline stations are rather easily identifiable by both their retail architecture (e.g., the presence of gasoline pumps) and, typically, through their 


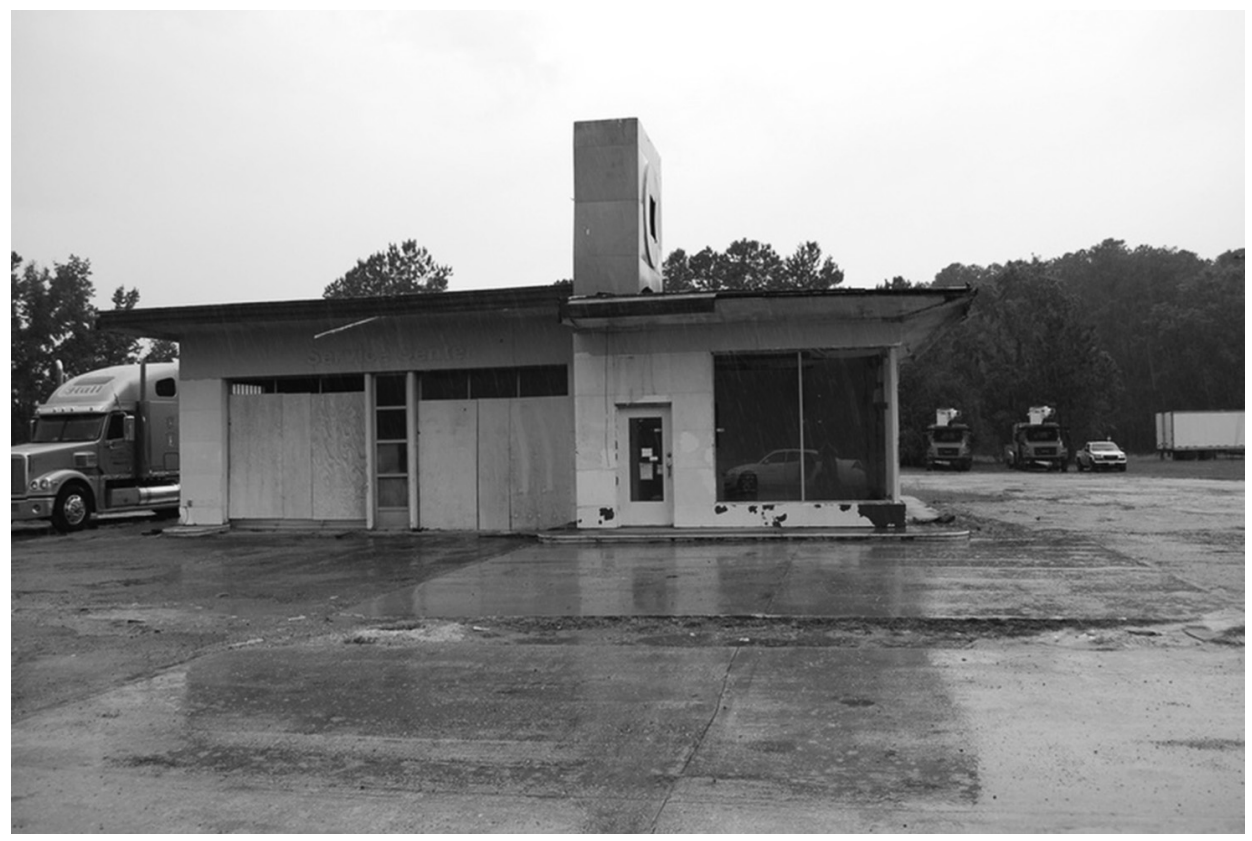

Figure 2. This former Shell station is an example of many of the abandoned gasoline stations located throughout the length of Virginia's Eastern Shore. Photo source: authors.

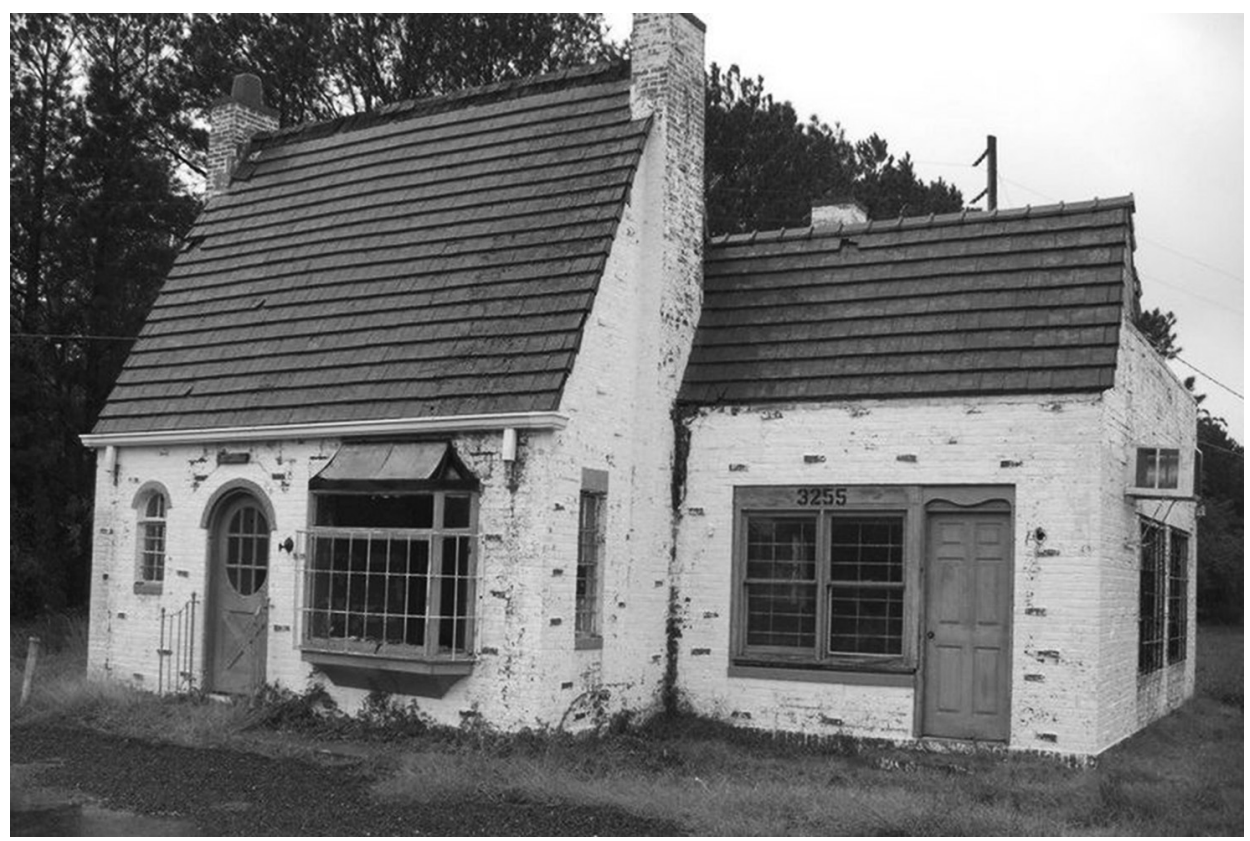

Figure 3. Pure Oil English cottage-style architecture with blue tile roof prevalent in the 1920s. This particular former gas station is located on the main road mid-way between the Town of Cape Charles and U.S. Route 13. Photo source: authors. 
corporate branding. Prior to the 1930s, gasoline stations were much more 'vernacular' in the sense that they were typically built by individual operators, which in turn meant that gasoline stations were individually unique and tended to reflect the architectural styles of their surrounding built environment, creating specific place associations for particular brands (Sculle 1981, p 57). However, gradual consolidation of the oil industry in the 1930s and 1940s demanded uniform architectural designs where motorists could readily recognize corporate brands "at a glance" (Sculle 1981, p 58) and associate expectations of "sameness of promised product and service" with each particular brand (Jakle and Sculle 1994, p 19). Associations with broader or national themes were favored in lieu of place-specific branding (Yergin 1991, p 210). For example, Standard Oil and most of its regional spin-offs following its antitrust breakup adopted red-whiteand-blue branding colors in order to appeal to a wider, national constituency by drawing from the colors of the U.S. national flag (Jakle and Sculle 1994, p 41). In essence, oil industry companies traded one geographical entanglement for another in their corporate branding in efforts to appeal to a national market (e.g., see Pike 2011). The Union Oil Company of California, for example, adopted its name ("Union") and the number 76 (from 1776, the year of American independence) as part of its logo and branding ("Union 76") to appeal to the national U.S. market. Phillips Petroleum Company, meanwhile, adopted the shield-shaped design of U.S. highway markers and the number 66 to connect its brand with the cultural and historical significance of U.S. Highway 66 (Jakle and Sculle 1994, p 40; see Krim 1998 regarding the cultural significance of U.S. Highway 66).
In many cases, corporate branding is embedded in the architecture of gasoline stations in order to differentiate between corporate brands by branding the most visible aspect of gasoline stations - the buildings themselves. Pure Oil, for example, was known for its English cottage-style gas stations with blue tile roofs that readily distinguished them from other corporate brands (Vieyra 1979, p 54; Jakle and Sculle 1994, p 138) (Figure 3). Gas station architecture is generally modernist-at least from the 1930s through the 1950 s, with enamel facades devoid of ornamentation-and largely functionalist, with the architecture reflecting the specific function of the gasoline service station: 'islands' containing gas pumps for fueling vehicles, garage bays for vehicle maintenance, and a small office for retail transactions including the sale of auto-related materials such as motor oil, transmission fluid, and the like (Lohof 1974; Jakle and Sculle 1994, p 167-180). Nevertheless, gas stations buildings were (and continue to be) largely adorned in the colors of particular corporate brands, including gas pump islands and canopies in order to distinguish them from other corporate brands.

Culturally, gasoline stations occupy a unique place in American roadside folklore (Vieyra 1979; Margolies 1993; Jakle and Sculle 1994; Summers and Priddy 2006). Beginning with the introduction of the assembly line-produced Ford Model T automobile in 1908, the retail price of automobiles in the United States decreased significantly and the number of registered vehicles skyrocketed (Jackson 1985, p 160-161). Nearly 10.5 million vehicles were registered by 1921 , and over 23.6 million vehicles were registered by 1930 (Jakle and Sculle 1994, p 51). And in the decades following World War II, vehicle 
registration surged even further, with nearly 62 million vehicles registered in 1960 to more than 137 million registered by 2008 (Federal Highway Administration 2009).

Moreover, the automobile revolution was initially far more impactful in the United States than anywhere else; by 1929 , 78 percent of the world's vehicles were sold in the U.S. (Yergin 1991, p 208). Gasoline consumption, meanwhile, surged as well, from nearly 4 million gallons in 1921 to more than 16 million in 1930 . By 1960 , more than 41 billion gallons were consumed, and a peak of more than 75 billion was reached in 2005 (Federal Highway Administration 2009). As gasoline consumption surged, so did the number of establishments that sold gasoline. In 1920, more than 100,000 retail establishments sold gasoline, but these were typically retailers such as general stores, grocers, and hardware stores. By 1930, the number of establishments selling gasoline had surged to 300,000 , and many of these were specifically gasoline service stations that at the time represented an entirely new form of retail establishment on the American landscape (Yergin 1991, p 209).

The increase in automobile ownership transformed the American urban and rural landscape. Beginning in the 1920s, more and more American households began moving away from urban centers, sparking a process of suburbanization that continues in the present. The Great Depression and World War II halted the process for more than a decade, but it quickly began anew following the war (Yergin 1991, p 550). The Interstate Highway Act of 1956 led to even greater transformations, and the process of suburbanization deepened further (Jackson 1985; Moon 1994;
Phelps, Wood, and Valler 2010). Moreover, with the U.S. economy booming-driven in part by the accumulation of capital as a result of suburbanization (Harvey 2003, p 108-115)-automobile ownership continued to increase. Indeed, an entire consumerist culture arose around the automobile, including 'strip' shopping centers, closed-in shopping malls, 'mo'tels, 'fast food' restaurants, recreational vehicle (RV) campgrounds, drive-through banking, drive-in movie theaters, car washes, and of course, gasoline service stations (Vieyra 1979; Jackson 1985; Yergin 1991; Jakle and Sculle 1999). By the 1960s, ninety percent of American households vacationed by car, and obtaining a learner's permit and driver's license have become a major rite of passage for generations of American teenagers (Jackson 1985, p 246; Yergin 1991, p 552). Together, these trends mark the emergence of a quintessential American 'roadside' culture defined by a built environment of vernacular commercial structures that functionally serve an automobile-centered economy. Jackson (1985) and Vieyra (1979) dub it a "drive-in" culture that has wholly transformed the American urban landscape, and continues to reshape it as suburbanization presses on and retail environments change to reflect the growing complexities of wider economic structures and consumer behaviors (Jones and Simmons 1990, p 243-277).

\section{LOCATION PATTERNS AND \\ FUNCTIONS OF GASOLINE STATIONS}

The earliest gasoline 'stations' were not gas stations at all, at least not as we know them today. Rather, they were general 
stores, repair shops, dry goods stores, and even livery stables for horses-all generally located in town centers-that sold gasoline to motorists by the bucketful (Vieyra 1979, p 3; Jackson 1985, p 256). Automobiles were still largely a novelty in the early 1900s and did not generate much demand for gasoline relative to kerosene, which was the major market for oil companies at the time (Yergin 1991, p 79). However, increasing popularity of the automobile (or "horseless carriage" as it was first known) eventually created a new market for the oil industry. Vehicle registrations, for example, soared from 8,000 in 1900 to 902,000 in 1912 (Yergin 1991, p 80), and to nearly 10.5 million by 1921 (Jakle and Sculle 1994, p 51). With general stores and grocers ill-equipped to handle rapidly increasing volumes in gasoline trade, motorists overwhelmed bulk storage tanks owned and operated by wholesalers on the outskirts of towns, causing disruptions in distribution operations (Vieyra 1979, p 4). The invention of gravity-fed tanks and hand-pumps in 1905 allowed for wider distributions of gasoline tanks. Existing general and hardware stores and grocers adopted these new gas tanks and pumps, placing them on curbsides in front of their stores. This, in turn, created new points of congestion as cars would line up for refueling at streetside tanks and block city streets for other motorists and pedestrians (Vieyra 1979, p 7). The solution would be the modern drive-in gasoline station dedicated entirely to the fueling and servicing of automobiles.

The growth in automobiles in combination with efforts to improve rural development also produced demand for a nationwide network of paved roads and highways (Weber 2005), and increased travels over longer distances spurred gasoline stations and other retail developments that would punctuate long stretches of open highways, giving rise to what Jakle and Sculle (1994) refer to as quintessentially 'roadside American culture.' New roads and highways and new traffic patterns meant the proliferation of drive-in gasoline service stations throughout urban and rural America, particularly along the most heavily traveled roadways and intersections, and gasoline stations have arguably become the most ubiquitous form of commercial building in the United States and a prominent feature of American suburbia (Vieyra 1979, p xiii; Jackson 1985, p 256).

The second wave of American suburbanization after World War II interestingly coincided with what has come to be recognized as the 'quantitative revolution' in geography (Berry 1993; Cox 2001). A robust body of work dedicated to geographical principles and processes important for retail location-for example, applications of central place theory to explain locations, size, spacing, and functions of "clusters of activity" (Berry 1967, p 3); to delineate geographical trade areas and to measure the impacts of new retailers on existing trade networks in an area (Applebaum and Cohen 1961; Clark 1968); to measure the geographical pull of select retail firms (Horton 1968; Bucklin 1971); to determine geographical factors for retail site evaluation and location (Cohen and Applebaum 1960; Getis 1963; Epstein 1971); and so on-emerged during the quantitative revolution and continues to flourish at present (e.g., see the works of Neil Wrigley, Tony Hernandez, Ken Jones, Neil Coe, and Thomas Graff, among others).

While most studies are concerned with intersections of geography with large re- 
tailers like department stores, furniture stores, retail corporations and marketing strategies, gasoline stations are perhaps so ubiquitous as to warrant very little inquiry, at least in terms of locational pattern and strategy. Further, in automobile-oriented societies like the United States, acquiring fuel for vehicles is a necessity regardless of income levels; consequently, retail oil companies are not largely concerned with distributions and clusters of particular income groups. Rather, gasoline station retailers are primarily concerned with traffic volume. Wherever traffic volumes are high -for example, along main arterial roadways, at intersections of primary and secondary roads, near clusters of retailing like shopping malls, or stationed near exit ramps of low-access high-speed freeways (Norris 1987)-you will find gasoline stations. Perhaps the closest related retail operation in terms of locational pattern is the fast-food restaurant which is also heavily dependent on high traffic volume (Norris 1987; Pillsbury 1987).

Patterns of gasoline station locations and their functions have nevertheless changed through the decades. The earliest gasoline retailers were typically general stores, hardware stores, grocers, and the like, and they were largely located in cities and town centers as noted above. As automobiles became more pervasive, gasoline service stations opened along roads and intersections with high traffic volumes, including those servicing residential neighborhoods. During this early stage of gasoline station development in the 1920s, gasoline station buildings were often built to look like houses in order to blend in with their surrounding neighborhoods (Jakle 1978). With the process of suburbanization and road networks becoming even more devel- oped, drive-in gasoline service stations largely drew away from urban centers and gravitated to high volume roadways and intersections and near long-distance highspeed freeway exit ramps (Norris 1987; Jake and Sculle 1994, p 201-224).

Aside from location patterns, the functions of gasoline stations have also changed through the decades. Early gasoline stations were primarily leased to and operated by independent local dealers who also provided vehicle maintenance services in addition to selling gasoline and other autorelated products (Jakle and Sculle 1994, p 57). Consequently, many of these early gasoline stations-including those built to look like houses-typically housed 'grease pits' or garage bays for vehicle maintenance, but these garages were usually added on to existing gas station buildings (Jakle and Sculle 1994, p 142). As oil industry retailers became more consolidated and their architecture standardized across space, garage bays were incorporated into their standardized architectural designs. But these designs changed, too. For example, as gasoline sales declined during the Depression in the 1930s, gasoline station retailers altered architectural designs in order to increase space for the sale of automobile accessories and to increase space for vehicle maintenance, which meant larger offices and garages. Gone, however, were hip and gable roofs, roof tiles, and house-style architectures in favor of oblong boxes with flat roofs (Jakle 1978; Jakle and Sculle 1994, p 143-144).

The oblong box design introduced in the 1930s is perhaps the most recognizable architectural design of gasoline stations among Americans even today. Indeed, the 1940s and 1950s saw the largest numbers of gasoline stations built as vehi- 
cle registrations and gasoline consumption soared following World War II (Jake and Sculle 1994, p 68). 'Streamlined' and easily reproducible-and malleable to accommodate corporate branding-the oblong box became the standard design for gasoline stations into the 1960s (Jakle and Sculle 1994). Moreover, the oblong box was seen as modernist and functional, with porcelain-enamel facades evocative of speed, modernity, and progress (Jakle and Sculle 1994, p 146). Different decades placed different stamps on the oblong box. The bubble-shape of offices and rounded exteriors dominated in the 1940s, which then gave way to more sharplydefined boxy edges in the 1950s (e.g., see Vieyra 1979). In the 1960 s, gasoline station architecture moved away from porcelain enameled exteriors and flat roofs to more ranch-style exteriors, including 'face-lifting' and 'top-hatting', to better blend in with their surrounding built environment (Jakle and Sculle 1994, p 150).

Technology has also led to changes in gasoline station design. The 1970s saw the emergence of credit card-accommodating, pay-at-the-pump self-service gasoline stations devoid of maintenance services and garages. These gasoline stations did not do away entirely with the oblong box; rather, the oblong box was dramatically shortened to accommodate only a small office for retail transactions. This self-service style of gasoline station came to dominate into the 1980s and beyond, but with the addition of convenience stores beginning largely in the late 1970s and early1980s (Johnson and Romeo 2000). In the 1990s, the 'super' convenience store with multiple canopied self-service gasoline pumpsand often in partnership with convenience store chains and/or with fast-food restau- rant chains-appear to have become the dominant model.

A number of factors-for example, the ever-changing urban and rural landscape and its retail environment combined with changes in gasoline station design and function (Vieyra 1979; Jones and Simmons 1990), changing automobile technologies such as the use of higher technology metals that are more resistant to corrosion, and higher technology engines requiring less maintenance and producing increasing average miles per gallon for new vehicles (Arenson 1983; Ford 2012), and changes in the nature of the gasoline retail business (e.g., increasing gasoline prices reducing profit rates and squeezing out independent dealers) (Campoy 2008)-have led to a steady decline in the number of gasoline stations in the United States (Federal Highway Administration 2009). Older gasoline stations located on roadways bypassed by newer, higher-volume arterials and highways have largely closed. Likewise for gasoline stations unable to adapt to new retail models (e.g., unable to accommodate convenience stores due to architectural or other constraints). Some are torn down, but many remain as either abandoned, run-down, or derelict structures. Others are transformed and recycled into new uses; in a sense, these recycled gasoline stations are like zombies-they may go out of business, but they live on after being converted into new uses (Figures 4 and 5).

The prevalence of both derelict and zombie gasoline stations on Virginia's Eastern Shore are testament to the changing forms and functions of gasoline stations. Moreover, they are evidence embedded in the landscape revealing the impact of wider economic and social forces-changes in 


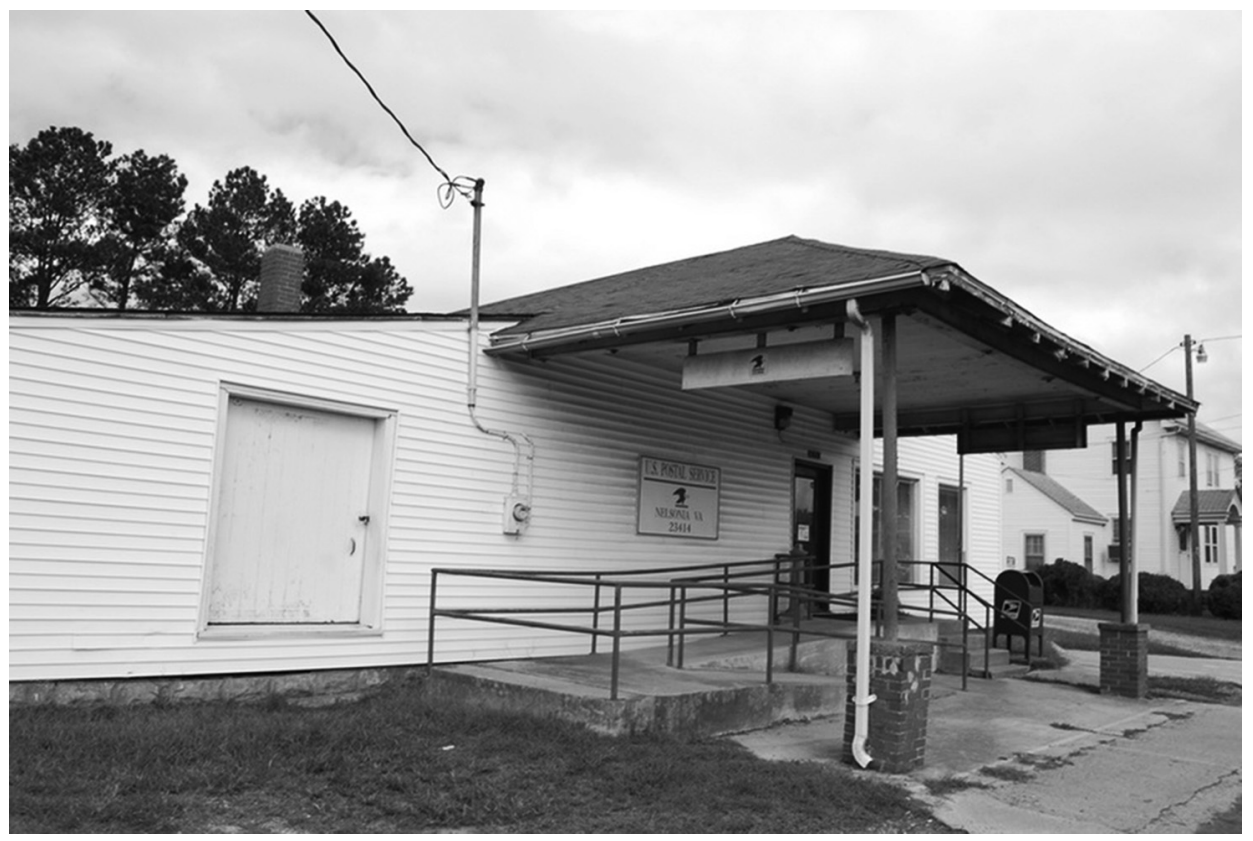

Figure 4. This US Post Office in Nelsonia, Virginia is an example of a recycled, or "zombie," gasoline station. Photo source: authors.

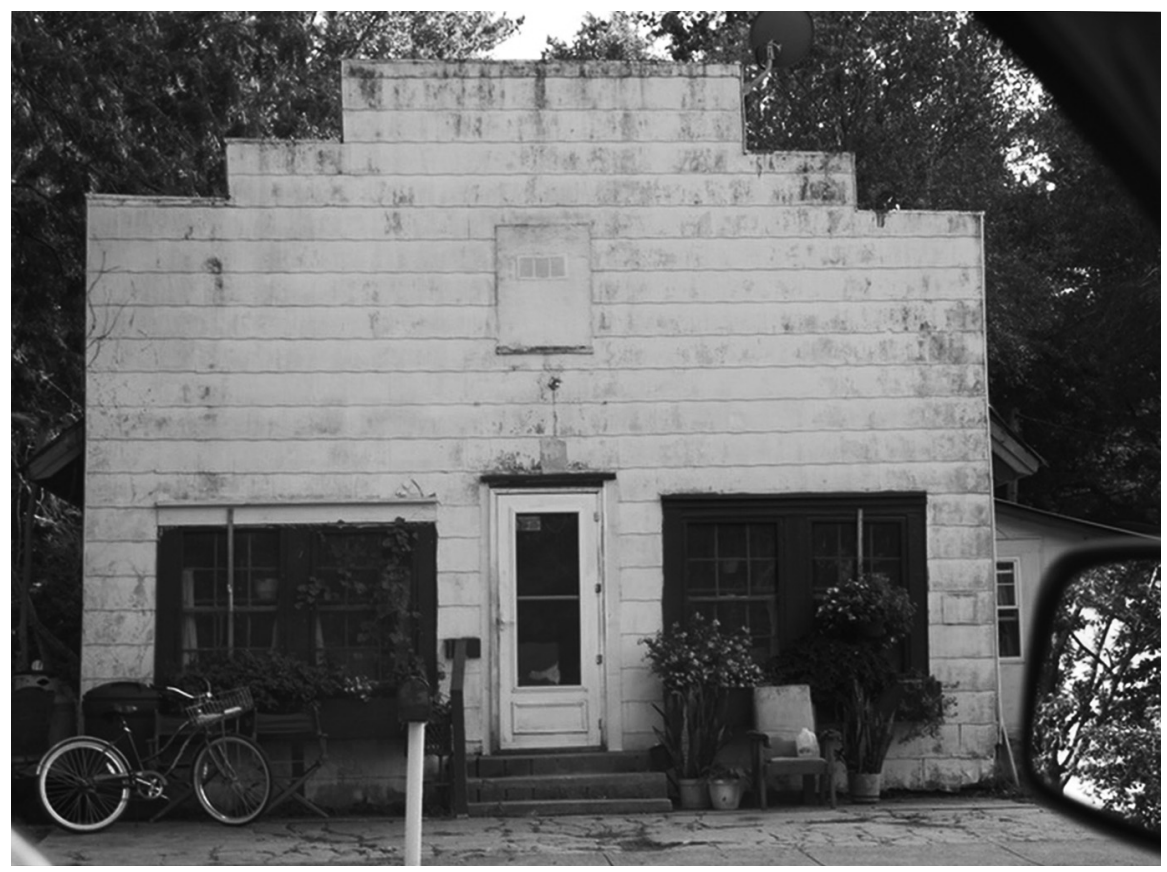

Figure 5. Another "zombie" gasoline station now a private residence in Exmore, Virginia. Photo source: authors. 
transportation networks and technologies and their impacts on central place hierarchies, changes in consumer behaviors, the changing nature of retailing, and so on. They represent forces of "creative destruction" and are physical remnants of time/ space compression (Harvey 1990), the discarded remains of outmoded and obsolete gasoline stations as modern automobiles go farther, last longer, and consume gasoline more efficiently. Derelict and zombie gasoline stations essentially represent visible echoes of an evolving past that is largely hidden in plain sight. We seek to unlock this past by mapping and categorizing by the decade of their construction all current and previous gasoline stations of Virginia's Eastern Shore. By doing so, we then explore changing geographical patterns of gasoline station locations and functions. It is to this task the paper now turns.

\section{DATA AND METHODOLOGY}

The data utilized in this study is the location of all gasoline stations, past and present, located throughout the entirety of Virginia's Eastern Shore (Figure 6). Gasoline station sites were identified through extensive field work conducted between September and December, 2011. Precise location coordinates were recorded utilizing ArcPad 6 mapping software in combination with a GPS receiver. Digital photographs were taken of every site and potential site and logged with a unique identifier. Brief discussions with local residents and post office clerks confirmed the previous existence of gasoline stations at sites where inconclusive evidence remained and also gave locations of other sites to investigate. Further, locational data from the Virginia Department of Environmental Quality (VDEQ) list- ing the addresses of existing and previouslyexisting underground storage tanks was utilized to proof much of the data, particularly for sites where buildings no longer exist but evidence of previous gasoline stations remain (e.g., the presence of concrete slabs, gasoline pump islands, and driveway entrances). Although the VDEQ data appeared to be spotty at best (our field work was more precise in comparison), two previously undiscovered gasoline station locations were found utilizing the VDEQ data.

We identified a total of 152 gasoline station sites located throughout Virginia's Eastern Shore, 52 of which are currently active (defined by still actively selling gasoline) (Figure 6). Note that the vast majority of active and inactive gasoline stations are located along U.S. Route 13, the primary roadway-a four-lane divided highway for most of its length-running down the spine of Virginia's Eastern Shore. In order to discern (changing) spatial patterns, we utilized digital photographs of all gasoline stations (active and inactive) to categorize each gasoline station by decade built based on their architectural style as defined in the works of Jakle (1978), Vieyra (1979), Margolies (1993), and Jakle and Sculle (1994) (Table 1). While architectural styles do not neatly conform to time categories entirely, decades nonetheless offer a generalized but effective method for categorizing gasoline station buildings as defined in the literature. It is possible that a small number of gasoline stations were miscategorized, but we are confident in both our categorizations and in the small impact miscategorization may have on our results.

For each decade, we utilize GIS to perform a point pattern analysis (namely a nearest neighbor analysis) to determine if 


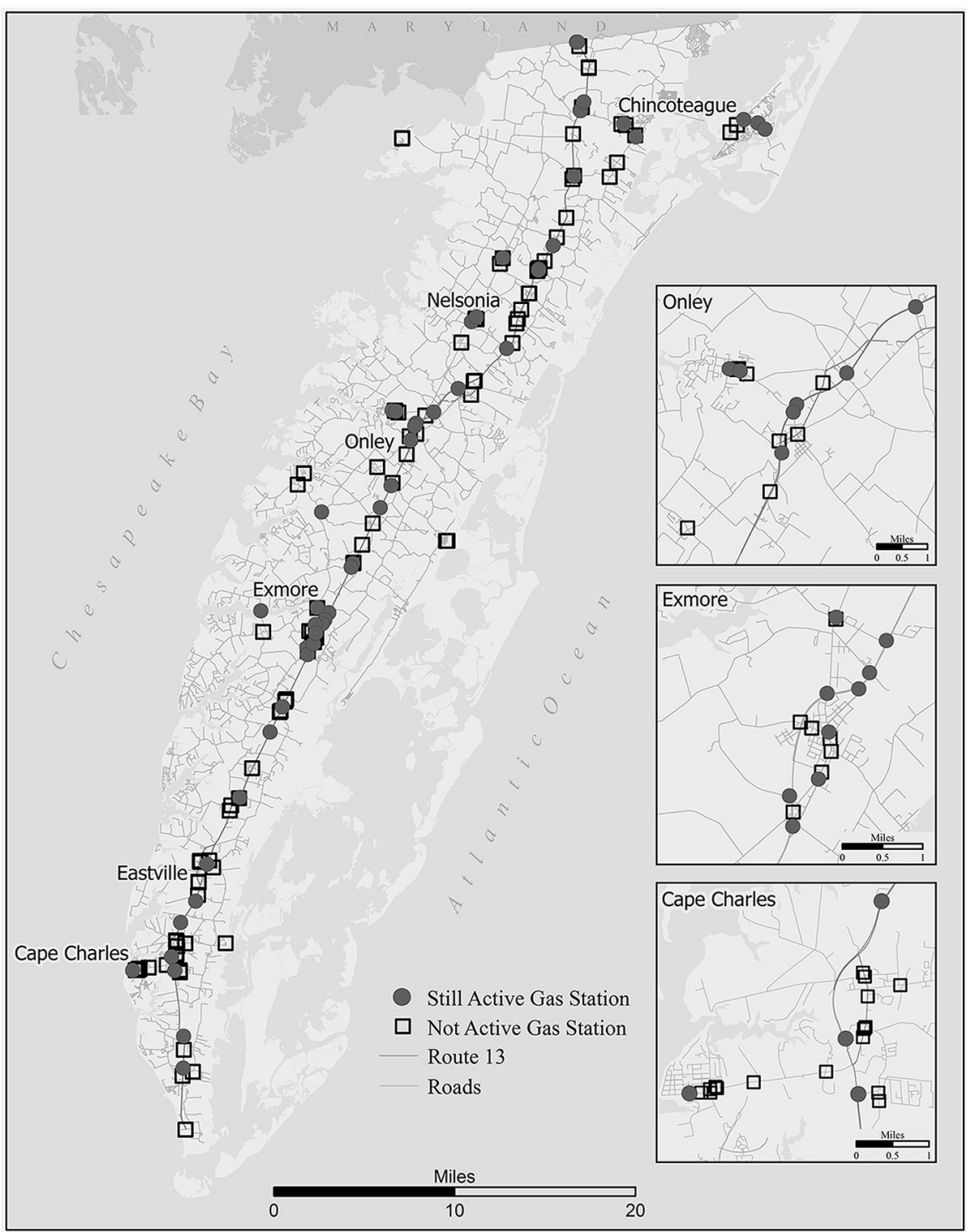

Figure 6. Gasoline station locations, active and inactive, on Virginia's Eastern Shore (2011).

gasoline stations were randomly distributed across Virginia's Eastern Shore or statistically clustered, indicating spatial autocorrelation, and to explore how these location patterns might have changed through time. For the nearest neighbor analysis, we generated a random distribution of 152 points along the road network of Virginia's Eastern Shore for comparison against observed locations, including 100 
Table 1. Categorization of gasoline stations by decade built.

\begin{tabular}{lccrcr}
\hline Decade built & Total & No. Active & \% Active & No. Inactive & \% Inactive \\
\hline Prior to 1930 & 11 & 1 & $9.09 \%$ & 10 & $90.91 \%$ \\
1930s & 28 & 1 & $3.57 \%$ & 27 & $96.43 \%$ \\
$1940 \mathrm{~s}$ & 20 & 1 & $5.00 \%$ & 19 & $95.00 \%$ \\
$1950 \mathrm{~s}$ & 33 & 5 & $15.15 \%$ & 28 & $84.85 \%$ \\
$1960 \mathrm{~s}$ & 19 & 7 & $36.84 \%$ & 12 & $63.16 \%$ \\
$1970 \mathrm{~s}$ & 18 & 15 & $83.33 \%$ & 3 & $16.67 \%$ \\
$1980 \mathrm{~s}$ & 13 & 12 & $92.31 \%$ & 1 & $7.69 \%$ \\
1990s+ & 10 & 10 & $100.00 \%$ & 0 & $0.00 \%$ \\
TOTAL & 152 & 52 & $34.21 \%$ & 100 & $65.79 \%$ \\
\hline
\end{tabular}

along U.S. Route 13 in order to account for the linearity of actual gasoline station locations spread along U.S. Route 13. We expect that gasoline stations are in fact clustered along particular intersections and arterial roadways with high traffic volumes given the retail function of gasoline stations. Further, the morphology of gasoline station form and function through time would suggest these clusters themselves change to accommodate changes in the gasoline station retail environment, and also to reflect advances in technologies such as more fuel-efficient and maintenanceefficient automobiles and the construction of high-speed, limited-access highways. Indeed, both Euclidean and Manhattan distances are utilized and presented in the nearest neighbor analyses. We expect that gasoline stations in earlier decades would be statistically clustered in Manhattan distances given their locations in town centers where the road networks are more gridlike. In later decades where gasoline stations are largely located in a linear fashion along U.S. Route 13 and parallel arterial roadways, we would expect that if gasoline station locations are statistically clustered, that they are clustered in Euclidean distances to reflect the linearity of the road pattern.

Descriptive data such as average proximity of active and inactive gasoline stations by decade to U.S. Route 13, and percentage of gasoline stations by decade built with garages or food marts, are also performed in order to explore gasoline station locations in relation to changing gasoline station form and function, and also gasoline station locations in relation to the changing socioeconomic structure of Virginia's Eastern Shore.

\section{RESULTS}

For each decade, gasoline station locations are largely scattered along U.S. Route 13, the main highway running up and down the center of Virginia's Eastern Shore (Figures 7-10). Prior to the 1930s, gasoline stations were few in number with just 11 scattered primarily south of the town of Onley (Table 1). Indeed, with such a few number of gasoline stations built prior to 1930 , the distribution is statistically random in both Euclidean and Man- 


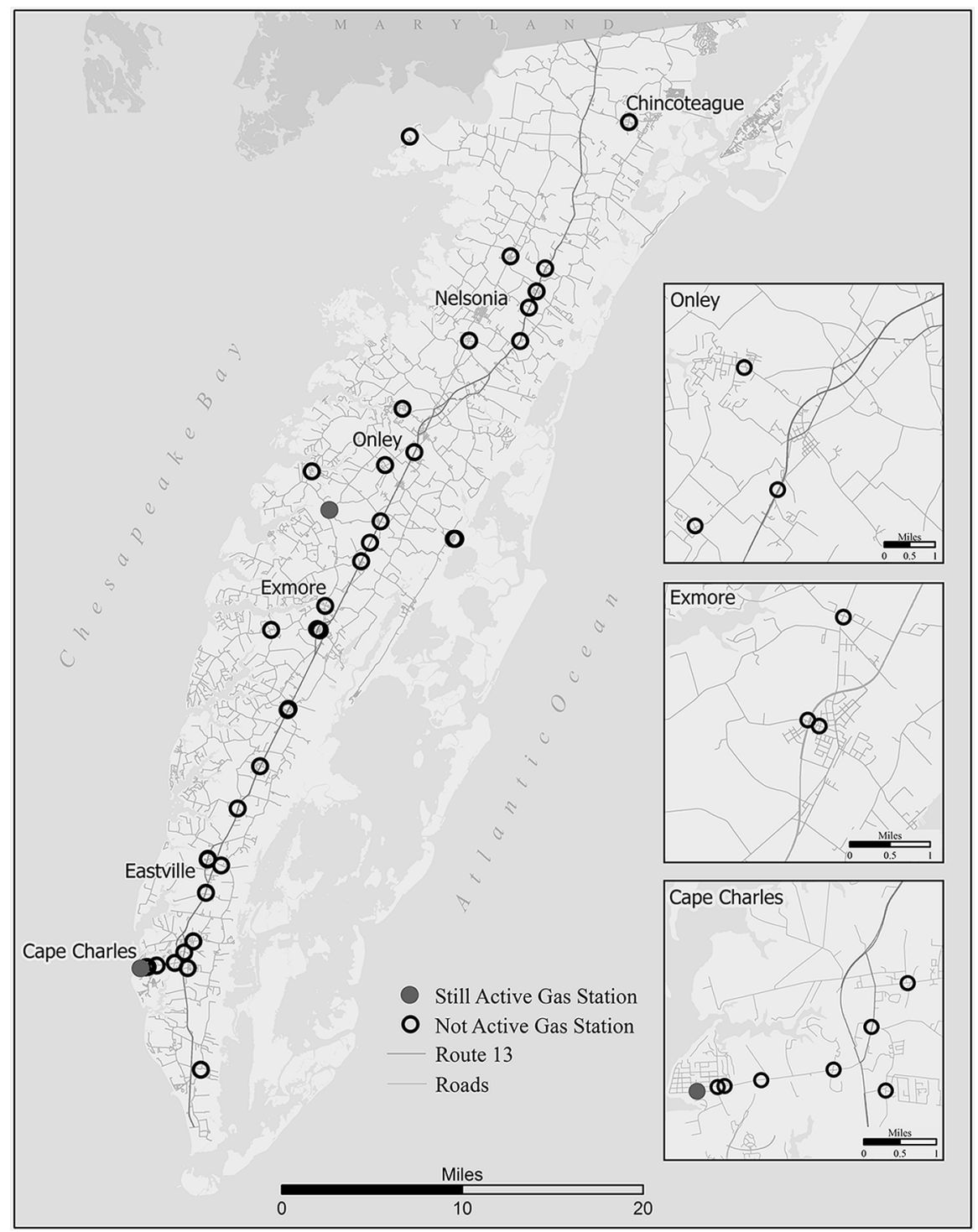

Figure 7. Gasoline stations on Virginia's Eastern Shore built in the pre-1930s and 1930s. 


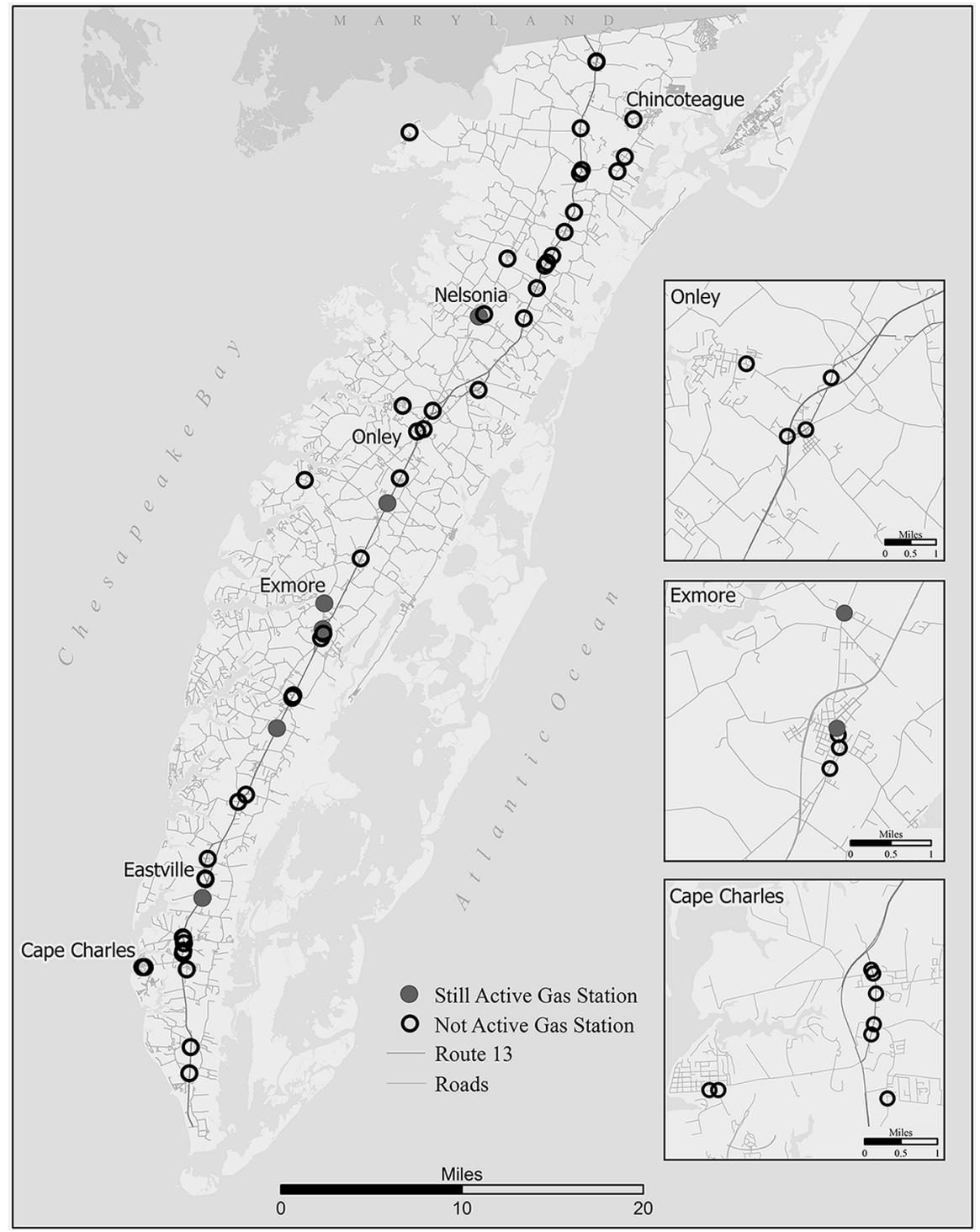

Figure 8. Gasoline stations on Virginia's Eastern Shore built in the 1940s and 1950s. 


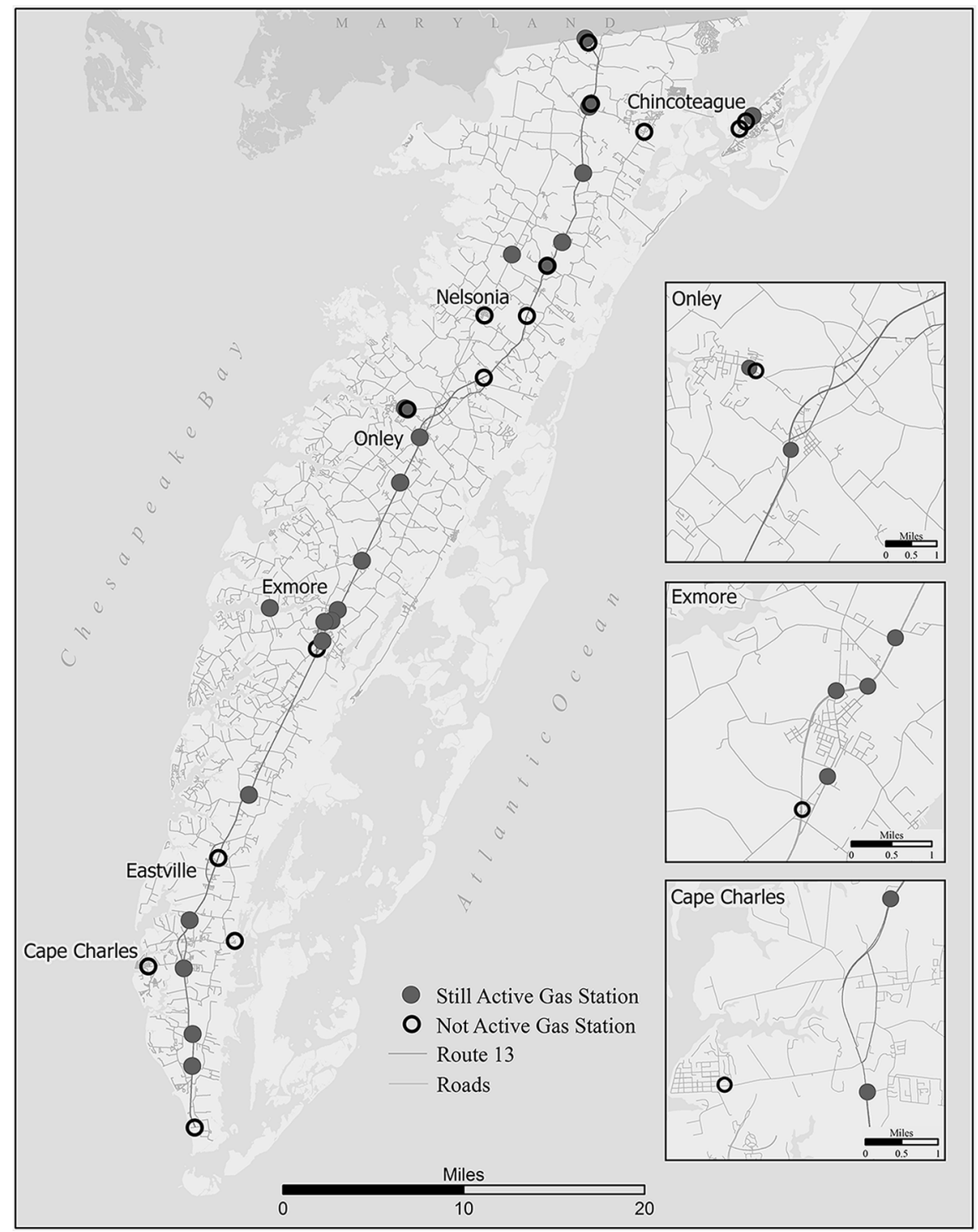

Figure 9. Gasoline stations on Virginia's Eastern Shore built in the 1960s and 1970s. 


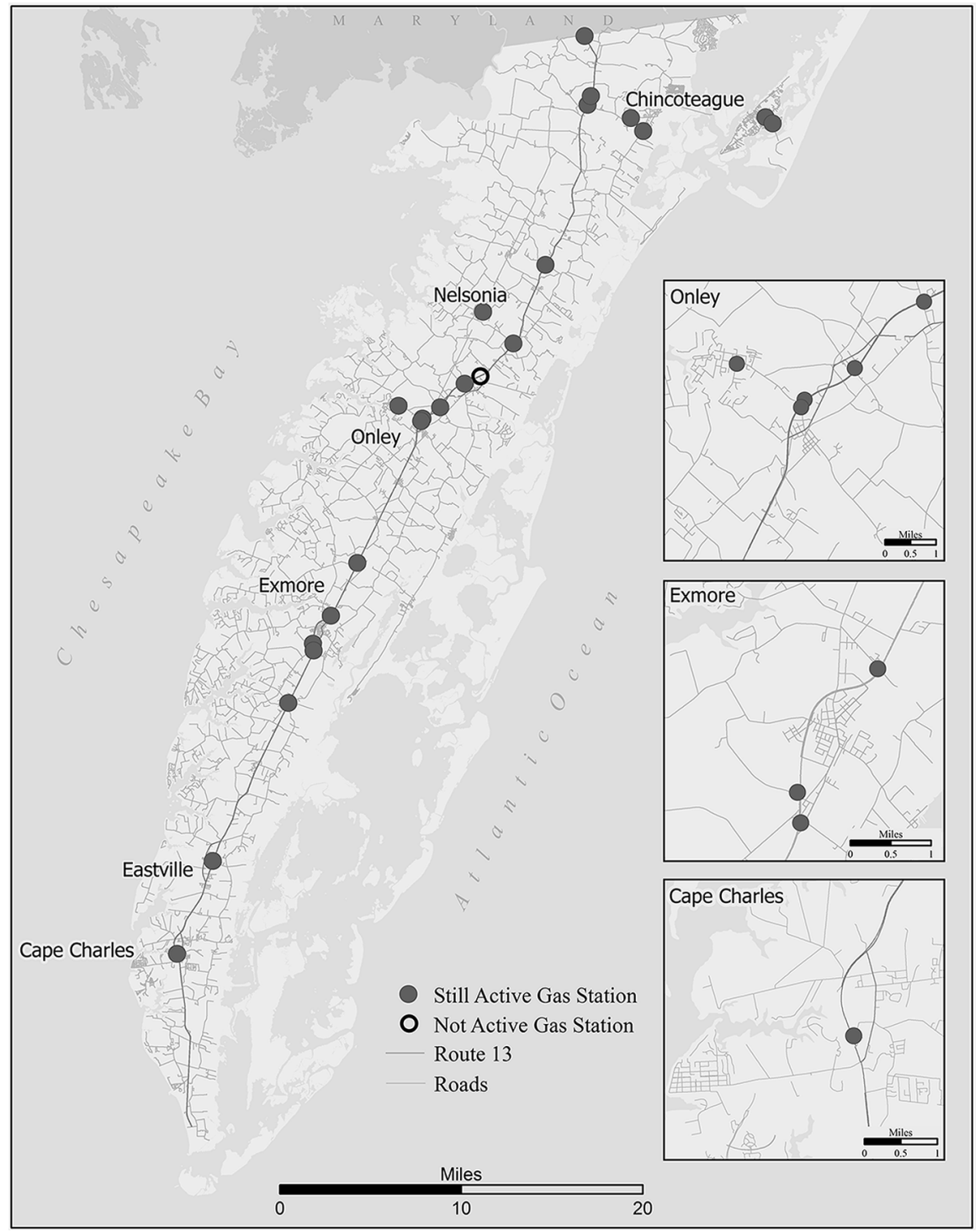

Figure 10. Gasoline stations on Virginia's Eastern Shore built in the 1980s and 1990s+. 
Table 2. Nearest neighbor analysis of gasoline station locations by decade.

\begin{tabular}{lccccc}
\hline & \multicolumn{2}{c}{ Euclidean Distance Nearest Neighbor } & & \\
\cline { 2 - 4 } & & p- & Observed Mean & & Expected Mean \\
& z- score: & value: & Distance: & & $\begin{array}{c}\text { Nearest Neighbor } \\
\text { Distance: }\end{array}$ \\
\hline$* * *$ Rall decades & -17.576 & 0.0000 & 550.3522 & 2159.8464 & 0.2548 \\
Pre-1930 & -1.457 & 0.1452 & 6185.2593 & 8028.7570 & 0.7704 \\
$* * * 1930 \mathrm{~s}$ & -3.203 & 0.0014 & 3440.0877 & 5032.2898 & 0.6836 \\
$* * * 1940 \mathrm{~s}$ & -2.593 & 0.0095 & 4149.5769 & 5954.2856 & 0.6969 \\
$* * * 1950 \mathrm{~s}$ & -6.518 & 0.0000 & 1886.2081 & 4635.4050 & 0.4069 \\
$* * 1960 \mathrm{~s}$ & -2.195 & 0.0282 & 4500.7991 & 6108.9681 & 0.7368 \\
$* * 1970 \mathrm{~s}$ & -1.960 & 0.0500 & 4760.4174 & 6276.3681 & 0.7585 \\
$1980 \mathrm{~s}$ & -1.565 & 0.1177 & 5710.2437 & 7385.3823 & 0.7732 \\
$* * 1990+$ & -2.397 & 0.0165 & 5084.7901 & 8420.6314 & 0.6038 \\
\hline
\end{tabular}

\begin{tabular}{lrcccc}
\hline & \multicolumn{2}{c}{ Manhattan Distance Nearest Neighbor } & & \\
\cline { 2 - 4 } & z- score: & $\begin{array}{c}\text { p- } \\
\text { value: }\end{array}$ & $\begin{array}{c}\text { Observed Mean } \\
\text { Distance: }\end{array}$ & $\begin{array}{c}\text { Expected Mean } \\
\text { Distance: }\end{array}$ & $\begin{array}{c}\text { Nearest Neighbor } \\
\text { Ratio: }\end{array}$ \\
\hline ***All decades & -16.032 & 0.0000 & 691.7327 & 2159.8464 & 0.3203 \\
Pre-1930 & 0.213 & 0.8313 & 8298.3876 & 8028.7570 & 1.0336 \\
$*$ 1930s & -1.663 & 0.0963 & 4205.5101 & 5032.2898 & 0.8357 \\
$* 1940 \mathrm{~s}$ & -1.735 & 0.0827 & 4746.4643 & 5954.2856 & 0.7972 \\
$* * * 1950 \mathrm{~s}$ & -5.337 & 0.0000 & 2384.4807 & 4635.4050 & 0.5144 \\
$1960 \mathrm{~s}$ & -1.034 & 0.3011 & 5351.3803 & 6108.9681 & 0.8760 \\
1970s & -0.767 & 0.4434 & 5683.6357 & 6276.3681 & 0.9056 \\
$1980 \mathrm{~s}$ & -0.290 & 0.7717 & 7074.7250 & 7385.3823 & 0.9579 \\
$1990+$ & -1.366 & 0.1719 & 6519.1549 & 8420.6314 & 0.7742 \\
\hline
\end{tabular}

$* * *$ denotes significance at the .01 confidence level; $* *$ at the .05 confidence level; * at the .10 confidence level; that distributions of gasoline stations by noted decades are not random and, indeed, are clustered.

hattan distances (Table 2). Four of the gasoline stations are located in or near the southernmost town of Cape Charles, however, and three in or near the town of Exmore. Further, all are located in or near the centers of towns.

The 1930s and 1950s saw the most gasoline stations built, with 28 and 33, respectively. For the 1930s, these gasoline stations appear to be scattered up and down the peninsula and primarily along U.S. Route 13, but nevertheless remain in or near the middle of towns (this is before bypasses were built in the early 1970s). Similarly for the 1950s, gasoline stations are located near population centers yet are stretched out further along U.S. 13 and other arterial roadways. Further, these gasoline station locations appear to be split northward and southward, with the center of the peninsula largely untouched because of the lack of a major town or population center as well the shape of the peninsula itself. For both decades, the dis- 
tributions are statistically clustered (at the .01 confidence interval for both Euclidean and Manhattan distances for the 1950s, and at the .01 and .10 intervals for the 1930s).

The 1940s represent a lag decade in terms of numbers of gasoline stations built, primarily due to gasoline rationing and a steep decline in demand during World War II, with only 20 stations built (Jakle and Sculle 1994, p 67). These gasoline stations also appear to be situated up and down the peninsula, but are actually statistically clustered at the .01 (Euclidean distance) and .05 (Manhattan distance) confidence intervals.

The 1960s sees a sharp decline in gasoline stations built, and that trend continues into the present. Virginia's Eastern Shore is geographically limited in space, and thus the number of gasoline stations built over the decades has largely filled in along the length of the peninsula (Figure 6). Nevertheless, all of the remaining decades after the 1950s are statistically clustered (Euclidean distance only) at the .05 confidence interval, with the exception of the 1980s, which are not statistically clustered. Indeed, from the 1960s onward, gasoline stations are located exclusively in areas with high traffic volumes and growing population centers.

Figures 7-10 illustrate changing spatial patterns of gasoline stations from pre-1930 to the present. The form and functions of gasoline stations located on Virginia's Eastern Shore changed dramatically through each of the decades. Consistent with the literature, the earliest gasoline stations (pre-1930 and 1930s) were largely intown country stores or in-town garageseven those located along U.S. Route 13. This was also true for the 1940s, but to a lesser degree. Most of the gasoline stations built from the 1930s onwards are located along U.S. Route 13, which was largely constructed circa 1926. The full length of U.S. 13 on the peninsula became primarily a 4-lane divided highway in the early 1970s, and the vast majority of stations built since then are located on U.S. 13, with the exception of a number of gasoline stations locating in the growing town of Chincoteague in the northeast of the peninsula.

The percentages of gasoline stations that also combined as a food mart dramatically decreased after the 1930s, but then reversed beginning in the 1960s. Onehundred percent of gasoline stations built from the 1990s include a food mart, and these are entirely super convenience stores with large square footage and multiple gasoline pumps. Inverse to the presence of food marts is the presence of garages for vehicle maintenance services. As the number of garages increased after the 1930s, the number of food marts inversely declined. Vice versa, as the number of gasoline stations with garages declined after the 1950s, the number of food marts inversely increased. Indeed, while all of the gasoline stations built from the 1990s have large convenient stores with food marts, none have garages for vehicle maintenance.

Finally, gasoline stations built from the 1930s onwards increasingly were located along U.S. Route 13 as gasoline stations pulled away from town centers and located along the primary highway of Virginia's Eastern Shore. Nevertheless, gasoline stations are generally not randomly distributed along the highway. Rather, gasoline station locations appear to be clustered for each decade with the exception of the 1980s, but clearly the clusters vary across decades. The economy of the Virginia East- 
ern Shore, while traditionally based on agriculture and commercial fishing-and largely still is-has nevertheless changed over the decades. The hierarchy of the peninsula's towns and the changing patterns of gasoline station locations reflect this change as some gasoline stations begin to locate away from U.S. 13 and towards growing tourist and employment centers like Chincoteague from the 1980s onwards. The rail and ferry hub of Cape Charles at the southwestern end of Delmarva held the largest overall population and greatest proportion of population relative to Northampton County in 1930, but its proportion of its county's population decreased until reversing in the 2000s. Cape Charles has become more of a tourist destination for visitors from the Hampton Roads area of Virginia in more recent years after becoming more accessible following completion of the Chesapeake Bridge-Tunnel in 1964. Chincoteague, in the northeast of the peninsula, meanwhile surpassed Cape Charles as the most populous town on Virginia's Eastern Shore in the 1940s, and its population in proportion to Accomack County has increased over the decades, surging particularly since the 1980s. Chincoteague is home to NASA's Wallops Island facility, established in 1945 and now representing Accomack County's largest employer. Chincoteague is also a growing coastal resort town, with a summertime population of approximately 35,000 (Fears 2011). The town of Exmore has also become a tourist destination, and its population has also grown as a proportion of Northampton County's overall population. Unsurprisingly, all four towns are home to the largest clusters of currently active gasoline stations (Figure 6).

Reflecting these changes in form and function, only three gasoline stations built in the decades from pre-1930 through the 1940s remain active-one from each decade-out of a total 59 built (Table 1 ). The decades with the highest percentages ( 80 percent or more) of active gasoline stations were those built in the 1970s to the present, with 92 percent of the gasoline stations built from the 1980s still active, and 100 percent of the stations built from the 1990s to the present still active.

Of the 100 gasoline stations built throughout the decades that are no longer actively selling gasoline, 61 are recycled (or zombie) gasoline stations operating under new uses (Table 3 ). It is notable that 46 (or 75 percent) of the zombie gasoline stations were built in the 1930s through the 1950s, which is reflective of both the malleability of the oblong box design prevalent during those decades, and the sheer number of gasoline stations built then. The majority of these are currently independent garages for vehicle maintenance. Indeed, 16 of the 61 zombie gasoline stations currently operate as independent garages, the largest zombie category; 11 serve as antique shops or flea markets, nine as restaurants, and seven as automobile dealership lots. Among the more interesting uses of former gasoline stations include five serving as homes or apartments, two as religious facilities (churches), one as a town hall and police station, and one as a U.S. post office (Figures 5 and 6).

\section{CONCLUSION}

Gasoline stations are a ubiquitous component of the modern built environment, both urban and rural. Gasoline stations clearly are included within people's daily spatial routines given the nature of modern 
Table 3. Categorization of new uses for recycled, or "zombie," gasoline stations.

Time Categories of Gasoline Stations by Decade

Pre-1930 1930s 1940s 1950s 1960s 1970s 1980s 1990+ Total

\begin{tabular}{lrrrrrrrrr}
\hline Vehicle Maintenance Facility & 0 & 1 & 5 & 8 & 2 & 0 & 0 & 0 & 16 \\
Antique and Flea Markets & 1 & 2 & 1 & 4 & 2 & 1 & 0 & 0 & 11 \\
Food Service & 1 & 4 & 2 & 2 & 0 & 0 & 0 & 0 & 9 \\
Vehicle Sales & 1 & 2 & 1 & 0 & 3 & 0 & 0 & 0 & 7 \\
Residential & 0 & 4 & 0 & 1 & 0 & 0 & 0 & 0 & 5 \\
Storage Facility & 1 & 1 & 0 & 2 & 1 & 0 & 0 & 0 & 5 \\
Government Facility & 0 & 1 & 1 & 1 & 0 & 0 & 0 & 0 & 3 \\
Real Estate Office & 1 & 0 & 0 & 2 & 0 & 0 & 0 & 0 & 3 \\
Religious Facility & 1 & 1 & 0 & 0 & 0 & 0 & 0 & 0 & 2 \\
& 6 & 16 & 10 & 20 & 8 & 1 & 0 & 0 & 61 \\
\hline
\end{tabular}

mobility, particularly in mobile societies like the United States, and represent a material infrastructure that underlies and facilitates daily economic activities. As such, gasoline stations are generally relegated to the background of contemporary cultural landscapes because the action of obtaining gasoline for one's vehicle has become such a routine and mundane activity that it is hardly given any forethought. Yet, the changing form and function of gasoline stations along with changing technologies in transportation and infrastructure has rendered many gasoline stations obsolete. And this process is by no means over. Consider the implications of policies regulating the use of fossil fuels as global climate change becomes a priority among scientists and policy-makers (Aspinall 2010; Smil 2011), or the impacts of potential future oil shortages (Bridge and Wood 2010) on future gasoline consumption. Gasoline stations will continue to change in form and function in response to changing consumer demand, leaving existing and future gasoline stations obsolete.

Obsolete gasoline stations still largely remain in the cultural and economic landscape, sitting either derelict and abandoned, or recycled into new uses (and often multiple times). Yet, because obtaining gasoline is such a routine and mundane activity (if increasingly financially painful) for the majority of Americans, gasoline stations both old and new have largely retreated from view, to be hidden in plain sight. Indeed, a rich cultural history is embedded in the landscape around us, a vernacular sequent occupancy (Whittlesey 1929) that holds the stories of our past if we are willing to see it. Finally, the act of obtaining gasoline to fuel modern mobility is performative in nature, an everyday geographical and cultural practice in which individuals intersect with wider social, economic, and political forces (Nash 2000; de Socio 2010). Active, derelict and zombie gasoline stations on Virginia's Eastern Shore reveal current and past cultural practices and economic functions reflective of life on the Shore, and how they have changed through the decades. As retail establishments directly tied to spatial patterns of modern human settlements 
and mobility, the changing form, function, and spatial distributions of gasoline stations on Virginia's Eastern Shore reflect the impacts of wider cultural and economic forces on the landscape through time, and everyday cultural practices of the past have largely faded from view even as they live on, if hidden, in plain sight.

\section{ACKNOWLEDGEMENTS}

The authors would like to thank Professor John Jakle and two anonymous reviewers for comments regarding an earlier draft of this article.

\section{NOTE}

1. This observation was first made by coauthor Bradley D. Macpherson, Geography major and member of Salisbury University's Sailing Club, during a team trip to a regatta held in the Hampton Roads area of Virginia.

\section{REFERENCES}

Arenson, K.W. 1983. "Number of gas stations expected to decline." Gainesville Sun, 6 March, p 7F.

Aspinall, R. 2010. Geographical perspectives on climate change. Annals of the Association of American Geographers 100(4):715-718.

Berry, B.J.L. 1967. Geography of market centers and retail distribution. Englewood Cliffs, NJ: Prentice-Hall.

_. 1993. Geography's quantitative revolution: Initial conditions, 1954-1960. A personal memoir. Urban Geography 14(5):434-441.

Bridge, G., and Wood, A. 2010. Less is more: Spectres of scarcity and the politics of resource access in the upstream oil sector. Geoforum 41:565-576.

Bunge, W. 1962. Theoretical Geography. First Edition. Lund Studies in Geography Series C: General and Mathematical Geography. Lund, Sweden: Gleerup.
Campoy, A. 2008. "Gas stations hit skids.” Wall Street Journal, 7 July.

Cox, K.R. 2001. Classics in human geography revisited: Bunge, W., Theoretical Geography. Commentary 1. Progress in Human Geography 25(1):71-73.

de Socio, M. 2010. Geographers mobilize: A network-diffusion analysis of the campaign to free Ghazi-Walid Falah. Antipode 42(2):310-335.

Fears, D. 2011. "Chincoteague fears proposal to move beach would hurt tourism, economy." Washington Post, 27 November.

Federal Highway Administration. 2009. Highway statistics 2009. Washington, DC: United States Department of Transportation.

Ford, D. 2012. "As owners pile on the miles, 200,000 becomes the new 100,000." New York Times, 16 March, p AU1.

Hartgen, D.T., and Kim, J.Y. 1998. Commercial development at rural and small-town interstate exits. Transportation Research Record 1649:95-104.

Harvey, D. 1990. The condition of postmodernity. Oxford, UK: Blackwell Publishers.

—. 2003. The new imperialism. New York: Oxford University Press.

Jackson, K.T. 1985. Crabgrass frontier: The suburbanization of the United States. New York: Oxford University Press.

Jakle, J.A. 1978. The American gasoline station, 1920-1970. The Journal of American Culture 1(3):520-542.

Jakle, J.A., and Wilson, D. 1992. Derelict landscapes: The wasting of America's built environment. Savage, MD: Rowman and Littlefield Publishers.

Jakle, J.A., and Sculle, K.A. 1994. The gas station in America. Baltimore: Johns Hopkins University Press.

_. 1999. Fast food: Roadside restaurants in 
the automobile age. Baltimore: Johns Hopkins University Press.

Johnson, R.N., and Romeo, C.J. 2000. The impact of self-service bans in the retail gasoline market. The Review of Economics and Statistics 82(4):625-633.

Jones, K., and Simmons, J. 1990. The retail environment. New York: Routledge.

Krim, A. 1998. "Get your kicks on Route 66!" A song map of postwar migration. Journal of Cultural Geography 18(1):49-60.

Lee, J. 1992. Spatial decision support systems for retail site selection. Papers and Proceedings of Applied Geography Conferences 15:68-74.

Lohof, B.A. 1974. The service station in America: The evolution of a vernacular form. Industrial Archeology 11:1-13.

Margolies, J. 1993. Pump and circumstance: Glory days of the gas station. Toronto: Bulfinch Press.

Moon, H. 1994. The interstate highway system. Washington, DC: Association of American Geographers.

Nash, C. 2000. Performativity in practice: Some recent work in cultural geography. Progress in Human Geography 24(4):653-664.

Norris, D.A. 1987. Interstate highway exit ramp morphology: Nonmetropolitan exit commerce on I-75. The Professional Geographer 39:23-32.

Phelps, N.A., Wood, A.M., and Valler, D.C. 2010. A postsuburban world? An outline of a research agenda. Environment and Planning A 42:366-383.

Pike, A. 2011. Placing brands and branding: A socio-spatial biography of Newcastle Brown Ale. Transactions of the Institute of British Geographers 36(2):206-222.

Pillsbury, R. 1987. From hamburger alley to Hedgerose Heights: Toward a model of restaurant location dynamics. The Professional Geographer 39(3):326-344.
Sculle, K.A. 1981. The vernacular gasoline station: Examples from Illinois and Wisconsin. Journal of Cultural Geography 1(2):56-74.

Smil, V. 2011. America's oil imports: A selfinflicted burden. Annals of the Association of American Geographers 101(4):712-716.

Summers, B.J., and Priddy, W. 2006. Value guide to gas station memorabilia. Paducah, KY: Collectors Books.

Vieyra, D.I. 1979. "Fill'er up": An architectural history of America's gas stations. New York: Collier Macmillan Publishers.

Weber, J. 2005. The morphogenesis of state highway networks in the United States. Journal of Historical Geography 31:723743.

Whittlesey, D. 1929. Sequent occupance. Annals of the Association of American Geographers 19(3):162-165.

Yergin, D. 1991. The prize: The epic quest for oil, money and power. New York: Simon and Schuster.

BRADLEY D. MACPHERSON is an undergraduate student and dual major in Geography and Earth Science, both in the Department of Geography and Geosciences at Salisbury University, Salisbury, Maryland. Email: bdm391@gmail.com. His major concentrations include GIS, atmospheric science, and human geography.

MARK DE SOCIO is Associate Professor of Geography in the Department of Geography and Geosciences at Salisbury University, Salisbury, Maryland. Email: mxdesocio@ salisbury.edu. His research interests are primarily urban politics, economic development, and social network analysis. 